\title{
SORPTION OF HEAVY METALS FROM POLLUTED WATER AND THEIR MIGRATION IN THE SYSTEM SOIL-TREE
}

\author{
Donatas Butkus ${ }^{1}$, Dainius Paliulis ${ }^{2}$, Edita Baltrènaité ${ }^{3}$ \\ Dept of Environmental Protection, Vilnius Gediminas Technical University, \\ Sauletekio al.11, LT-10223,Vilnius-40, Lithuania.E-mail:1,2aak@ap.vtu.lt, 3edita@ap.vtu.lt
}

Received 29 Jun 2004; accepted 27 Oct 2004

\begin{abstract}
Large amounts of various contaminants are transported via natural processes from technogenic pollution sources to air, water, soil and natural ecosystems. Heavy metals (HM) are very hazardous substances having long-lasting impact on ecosystems. They have complex negative impact on human health, animals, flora and fauna at watercourses and microflora of wastewater. Often concentration of HM exceeds maximal available concentration in wastewater. $\mathrm{HM}$ enter forests in their wet and dry forms from local or outer atmosphere sources; they are also brought from seas alongside with biogens and sea salt or washed from putrid or putrescent plants that concentrate in the soil or they are brought by wind or water together with mineral particles. Monitoring of forests determined that contaminants, i e HM inhibit energetic status of a tree and cause increase of tree sensitivity to diseases.

In this paper the most commonly met $\mathrm{HM}$, such as $\mathrm{Ni}, \mathrm{Mn}, \mathrm{Zn}, \mathrm{Pb}, \mathrm{Cu}$ and $\mathrm{Co}$, are analysed. Pollution with $\mathrm{HM}$ can be reduced, if HM are accumulated by plants or absorbed by porous substances.

Natural or synthetic sorbents due to their high sorption capacity, selectivity, the properties of cation exchangeability, a low price and affordability are used to remove HM from wastewater. We investigated activated carbon (AC) CKT and activated carbon (AC) UPA. The results of the investigation show that AC UPA cannot sorb HM and another sorbent AC CKT - cannot sorb HM too.

The transfer factor of HM from the soil to pine and birch trees was calculated, and the concentration of HM was determined in pine and birch wood, soil and polluted water. Samples of wood were burned, samples of soil were dried, and those of polluted water were analysed without special preparation. HM from wood and soil were extracted using a nitric acid solution. Samples of soil, wood and water were analysed with an atomic absorption spectrophotometer Buck Scientific $210 \mathrm{VGP}$.

It is determined that $\mathrm{Ni}$ and $\mathrm{Mn}$ are most effectively transferred from soil to both pine and birch wood, while $\mathrm{Cu}$ is less effective in accumulation in pine wood and $\mathrm{Co}-$ in birch wood.
\end{abstract}

Keywords: water pollution, soil pollution, wood, heavy metals (HM), birch, pine, activated carbon (AC), sorption, migration, transfer factor.

\section{Introduction}

Heavy metals (HM) are very hazardous substances having long-lasting impact on ecosystems [1]. They have complex negative impact on human health, animals, flora and fauna at waters courses and microflora of wastewater [2].

Large amounts of HM are transported via natural processes from technogenic pollution sources to air, water, soil and natural ecosystems. Commonly, the concentration of HM exceeds maximal available concentration in water (wastewater) and soil [3].

$\mathrm{HM}$ enter forests in their wet and dry forms from local or outer atmosphere sources; they are also brought from seas alongside with biogens and sea salt or washed from putrid or putrescent plants that concentrate in the soil or they are brought by wind or water together with mineral particles [4-7].

Monitoring of forests determined that contaminants, i e HM, inhibit the energetic state of a tree and cause increase of tree sensitivity to diseases.

We selected the most common $\mathrm{HM}$, such as $\mathrm{Ni}$, $\mathrm{Mn}, \mathrm{Pb}, \mathrm{Cu}, \mathrm{Zn}$ and $\mathrm{Co}$, for our investigation. The transfer factor of HM from the soil to a pine and birch trees can be calculated, and the concentration of HM was determined in the pine and birch wood, soil and polluted water. 
Natural or synthetic sorbents for their high sorption capacity, selectivity, properties of cation exchangeability, a low price and affordability are used to remove HM from wastewater [8].

The purpose of the investigation is to estimate the sorption properties of AC CKT and UPA for HM removal from an aqueous solution, and also to set transfer coefficients of HM from the soil to pine and birch wood. These trees and the mentioned sorbents were used for evaluation of HM removal from polluted soil (tree uptake) and from polluted water (sorbents).

\section{Methodology of investigation}

a) Materials, reagents and instruments

1. 3-6 mm diameter black grains of AC CKT;

2. 3-6 mm diameter black grains of AC UPA;

3. Samples of soil and wood;

4. Deionized water with electrical conductance $(0,05-0,08) \mu \mathrm{S} / \mathrm{cm}$;

5. Aqueous solutions of zinc and nickel mix with concentrations of $2 \mathrm{mg} / \mathrm{l}$, that were prepared, accordingly, from nitrates of zinc, copper and manganese (pure analysis);

6. Concentrated nitric acid (pure analysis);

7. Muffle furnace;

8. Percolators;

9. Atomic absorption spectrophotometer Buck Scientific, model 210 VGP;

10. Deionizator - „Demiwa 3 Roi”.

11. Analytical balance, model VLR-200.

\section{b) Sampling}

Samples of trees and soil

The pine and the birch - trees common in Lithuanian forests - were chosen for the investigation (both are approximately $30 \mathrm{~m}$ high, $0,4 \mathrm{~m}$ thick, $55 \mathrm{y} \mathrm{o}$ ). Thus, the results of the investigation on them are characteristic of forested locations situated close to pollution sources. Soil samples were taken from around a pine and a birch following the scheme given in Fig 1 .

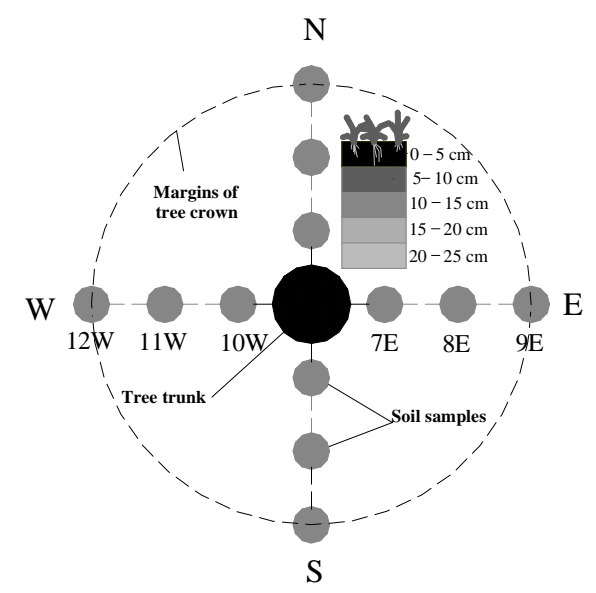

Fig 1. Scheme of soil sampling
Taking into consideration the wind direction prevailing in Lithuania, soil samples were taken from the western and eastern sides of the trees. Samples for measuring the HM concentration dependence on the soil depth were taken at a depth of $0-5 \mathrm{~cm}, 5-10 \mathrm{~cm}, 10$ $15 \mathrm{~cm}, 15-20 \mathrm{~cm}$ and $20-25 \mathrm{~cm}$, accordingly. The distance between soil-sampling points was $1 \mathrm{~m}$, and the sampling line was along the prevailing wind direction in the sampling site (west-east).

The trees under study grew in the southern part of Lithuania, about $10 \mathrm{~km}$ to the south from the town of Alytus. The soil there was podzolic, meanly podzolized, with an average acidity of about 5,5 pH. The relief was hilly (3-5\% incline). The forest floor thickness was 5$7 \mathrm{~cm}$, the green moss was the prevailing vegetation of the under-crown area. An average yearly temperature in this region was $6,0{ }^{\circ} \mathrm{C}$. The prevailing wind was from the west and the wind speed was $4,2 \mathrm{~m} / \mathrm{s}$. An average yearly amount of precipitation was $610 \mathrm{~mm}$.

\section{c) Preparation of samples}

AC samples. AC CKT and UPA was heated at a temperature of $100-105^{\circ} \mathrm{C}$ for $4 \mathrm{~h}$ up to a stable weight. Heated sorbent was cooled in a desiccator, filled with calcium chloride, up to room temperature and a different weight of sorbent $(0,25 \mathrm{~g} ; 0,5 \mathrm{~g} ; 1 \mathrm{~g} ; 2 \mathrm{~g} ; 4 \mathrm{~g})$ was weighed out with the analytical balance.

Adequate salts of $\mathrm{Cu}, \mathrm{Mn}$ and $\mathrm{Zn}$ (nitrates) were chosen as a source of HM. During weight calculations we paid attention to the class of clearness. Salt is dissolved in $800 \mathrm{ml}$ of deionized water and diluted till the sign in a $1000 \mathrm{ml}$ capacity flask. After attenuation of these solutions with deionized water, mixes of heavy metals of these concentrations were prepared:

$\mathrm{C}_{\mathrm{Cu}}-2 \mathrm{mg} / \mathrm{l}+\mathrm{C}_{\mathrm{Mn}}-2 \mathrm{mg} / \mathrm{l}+\mathrm{C}_{\mathrm{Zn}}-2 \mathrm{mg} / \mathrm{l}$

A different weight of AC CKT and UPA was weighed for the sorption of HM from an aqueous solution. Sorbent was filled up with $25 \mathrm{ml}$ of an aqueous solution of HM-salt mix and seasoned for 24 hours.

\section{d) Chemical analysis of samples}

Wood samples. $5 \mathrm{~cm}$-cylinders were cut off from a tree trunk. Samples were taken from the upper part of the tree - at $3 / 4$ height of the trunk, the middle of the trunk, and the bottom of the trunk ( $1 \mathrm{~m}$ from the stump). The cylinders were cut into slivers (width of two annual rings) in the direction of the tangent. The samples in the form of slivers were dried and, later, burnt. The mass of each tree sample was 30-40 g. Burning was carried out in ceramic vessels in a muffle furnace at $480{ }^{\circ} \mathrm{C}$ for 2 hours. Before burning, the slivers were weighed, and after burning the ash was weighed.

Soil samples. Soil was ground, mixed and screened through a screen with $\varnothing 1 \mathrm{~mm}$ meshes. The mass of each soil sample was $30 \mathrm{~g}$.

AC samples. The quantity of $\mathrm{HM}-\mathrm{Cu}, \mathrm{Mn}$ and $\mathrm{Zn}$ from an aqueous solution, sorbed by AC CKT and UPA, was analysed with an atomic absorption spectrophotom- 
eter Buck Scientific 210 VGP with flame. Deionized water was used as a zero solution. A standard solution of metal was made from a standard solution of $1 \mathrm{~g} / 1$ concentration.

Wood samples. 0,5-1,0 g samples were formed of wood ash. The ash of each sample was poured into a heat-resistant glass vessel and kept there for 24 hours infused with $100 \mathrm{ml}$ of $20 \%$ nitric acid. If the ash failed to melt well the obtained solution was boiled for up to 15 minutes in a draught cabinet. Then it was filtrated and diluted with $2 \%$ nitric acid. A control sample containing no ash was prepared in a similar way.

Soil samples. $30 \mathrm{~g}$ soil samples were heated for 2 hours at $100{ }^{\circ} \mathrm{C}$ so that humidity evaporates and then cooled to the room temperature and $25 \mathrm{~g}$ of each sample was taken. Later, the organic compounds remaining in the soil were burnt at $450{ }^{\circ} \mathrm{C}$ in the course of 3 hours. Then the samples, melted in $20 \%$ nitric acid, were boiled for $15 \mathrm{~min}$ in the draught cabinet in a heat-resistant glass vessel. The sample - still hot - was filtrated and diluted with $2 \%$ nitric acid. A control sample was prepared in the same way. HM concentrations in the wood and soil samples were determined using an atomic absorption spectrophotometer Buck Scientific 210VGP.

\section{Results and discussion}

The results of experimental investigation on HM sorption from water solutions of HM mixes depending on the sorbent mass (AC CKT and UPA) are submitted in Figs 2-4. Experiments were done with a different mass of sorbents: 0,$25 ; 0,50 ; 1,00 ; 2,00$ and $4,00 \mathrm{~g}$.

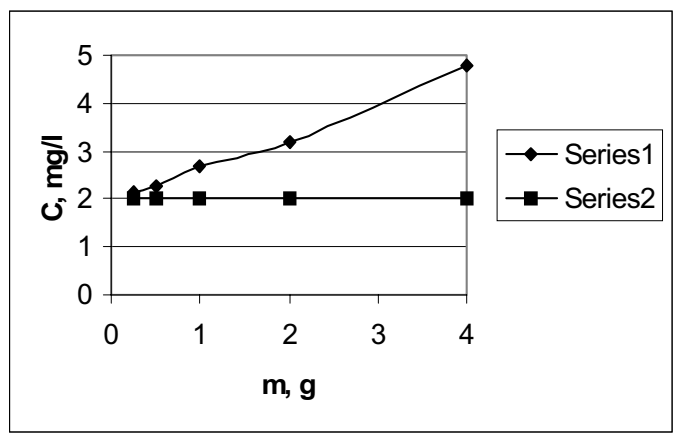

Fig 2. Dependence of HM sorption from aqueous solution on sorbent mass $\left(t=20^{\circ} \mathrm{C}, \mathrm{C}_{\mathrm{Cu}}=2 \mathrm{mg} / \mathrm{l}\right): 1-\mathrm{AC}$ CKT, 2 - AC UPA

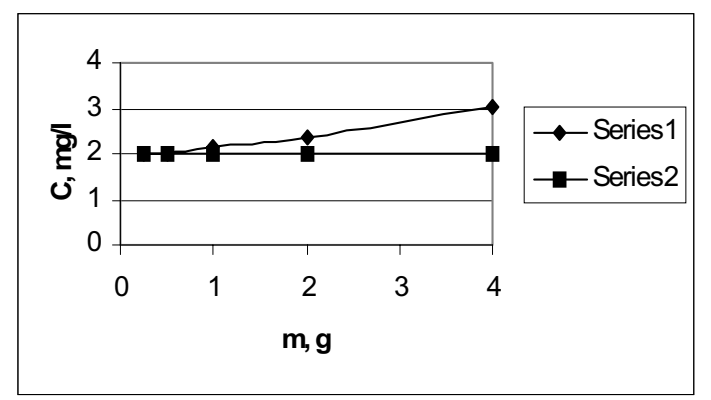

Fig 3. Dependence of HM sorption from aqueous solution on sorbent mass $\left(t=20^{\circ} \mathrm{C}, \mathrm{C}_{\mathrm{Mn}}=2 \mathrm{mg} / \mathrm{l}\right): 1-\mathrm{AC}$ CKT, 2 - AC UPA

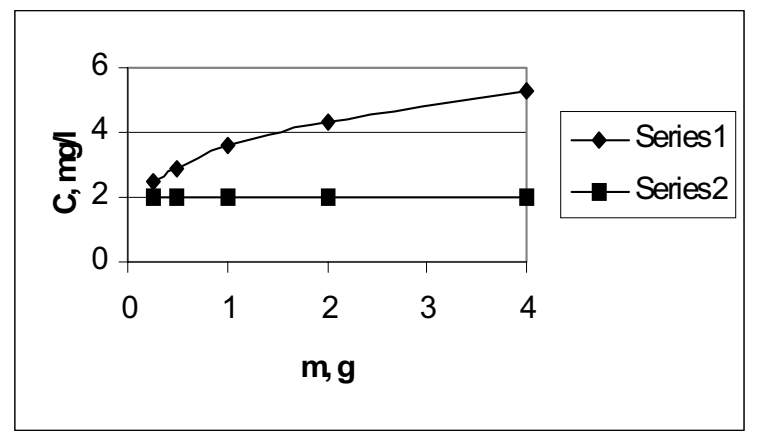

Fig 4. Dependence of HM sorption from aqueous solution on sorbent mass $\left(t=20{ }^{\circ} \mathrm{C}, \mathrm{Zn}=2 \mathrm{mg} / \mathrm{l}\right): 1-\mathrm{AC}$ CKT, 2 - AC UPA

From Fig 2 we can see that AC CKT from an aqueous solution cannot sorb Co. AC CKT includes Co, and Co can dissolve in water. The value of Co concentration in solution depends on the mass of sorbent. Then the mass of sorbent is growing, and the concentration of Co in solution is growing too. AC UPA is indifferent to $\mathrm{Co}$ in an aqueous solution.

From Fig 3 we can see that AC CKT from an aqueous solution cannot sorb Mn. AC CKT includes Mn, and $\mathrm{Mn}$ can dissolve in water. The value of $\mathrm{Mn}$ concentration in solution depends on the mass of sorbent. Then the mass of sorbent is growing, and the concentration of $\mathrm{Mn}$ in solution is growing too. AC UPA is indifferent to $\mathrm{Mn}$ in an aqueous solution.

The results of the investigation show that, analogous to Figs 2 and 3, we can see that AC CKT from an aqueous solution cannot sorb Zn (Fig 4). AC CKT includes $\mathrm{Zn}$, and $\mathrm{Zn}$ can dissolve in water. The value of $\mathrm{Zn}$ concentration in solution depends on the mass of sorbent. Then the mass of sorbent is growing, and the concentration of $\mathrm{Zn}$ in solution is growing too. After experimental investigation on removal of HM from aqueous solutions the possibility of AC CKT and AC UPA to sorb $\mathrm{HM}(\mathrm{Mn}, \mathrm{Cu}, \mathrm{Zn})$ from aqueous solutions was estimated. The results of the investigation show that $\mathrm{AC}$ UPA is indifferent to HM and it cannot sorb HM. According to the investigation results, HM cannot be removed from aqueous solutions with the help of AC CKT or AC UPA.

Experimental investigation results on HM concentration changing at a different depth of the soil around a pine-tree are given in Fig 5.

The soil depth of $10-20 \mathrm{~cm}$ is a layer where the main pine roots mass is concentrated. This implies that trees uptake the largest part of HM at this particular soil depth. Fluctuation of $\mathrm{Co}, \mathrm{Cr}$ and $\mathrm{Cu}$ concentrations in deeper soil layers are negligible (Fig 5), while the concentration of $\mathrm{Pb}$ is mostly concentrated in upper soil layers (Fig 5).

Investigating the concentrations of HM in the soil around a pine west-eastwards, it is observed that the concentrations of HM have a tendency to increase in the soil around a pine on windward side towards the 


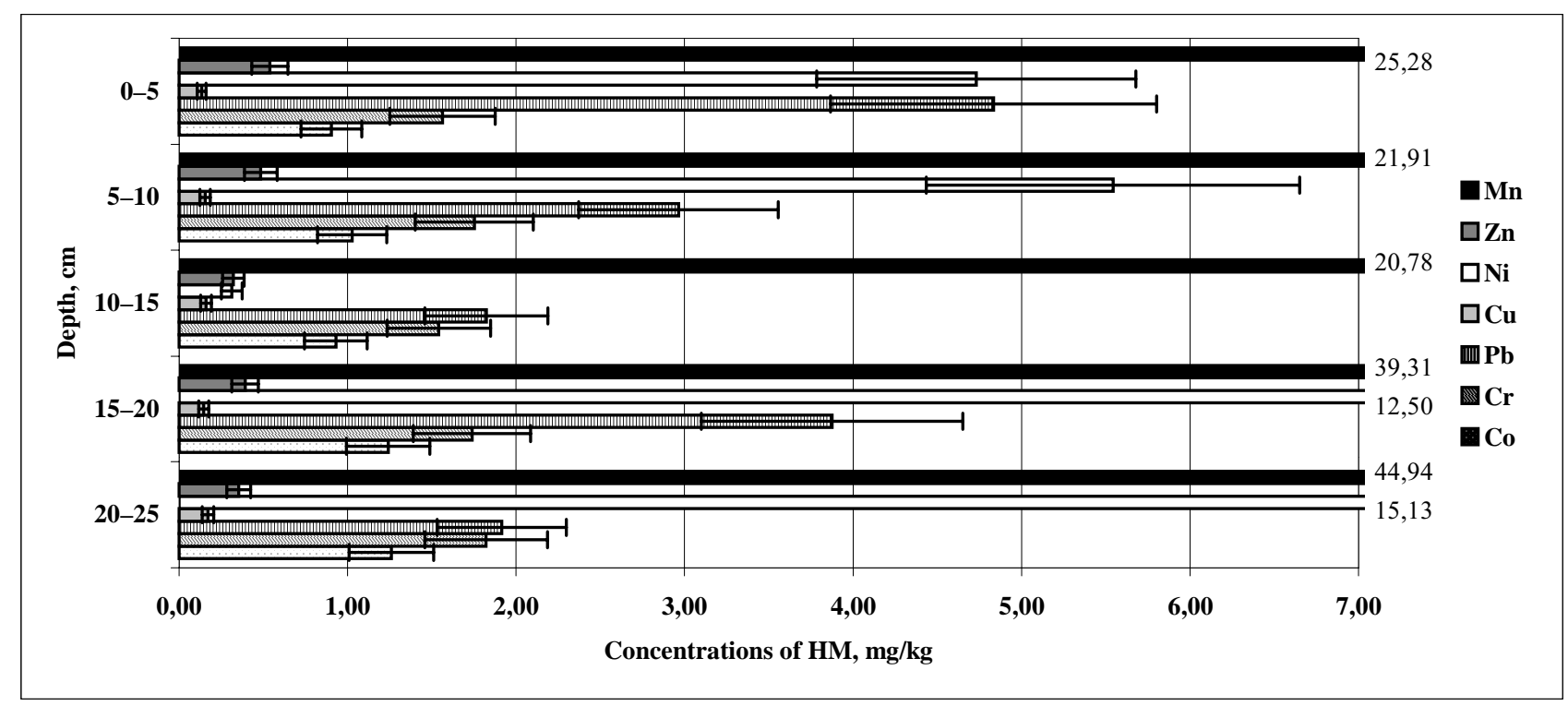

Fig 5. Concentrations of HM in the soil around a pine-tree

Concentrations of HM (mg/kg) downwind in the soil around a pine (P) and birch (B) (E - eastern direction, W - western direction)

\begin{tabular}{|c|c|c|c|c|c|c|c|c|c|c|c|c|c|c|}
\hline & \multicolumn{2}{|c|}{ Co } & \multicolumn{2}{|c|}{$\mathrm{Cr}$} & \multicolumn{2}{|c|}{$\mathbf{P b}$} & \multicolumn{2}{|c|}{$\mathbf{C u}$} & \multicolumn{2}{|c|}{$\mathbf{N i}$} & \multicolumn{2}{|c|}{ Zn } & \multicolumn{2}{|c|}{ Mn } \\
\hline & $\mathbf{P}$ & B & $\mathbf{P}$ & B & $\mathbf{P}$ & B & $\mathbf{P}$ & B & $\mathbf{P}$ & B & $\mathbf{P}$ & B & $\mathbf{P}$ & B \\
\hline $12 \mathrm{~W}$ & 1,28 & 1,26 & 2,06 & 2,18 & 9,03 & 7,52 & 0,19 & 0,18 & 2,08 & 5,42 & 0,46 & 0,51 & 33,70 & - \\
\hline $11 \mathrm{~W}$ & 0,90 & 1,38 & 1,56 & 2,64 & 4,83 & 7,89 & 0,13 & 0,25 & 4,73 & 0,31 & 0,54 & 0,52 & 21,91 & - \\
\hline $10 \mathrm{~W}$ & 0,78 & 1,38 & 1,89 & 2,31 & 10,9 & 7,41 & 0,17 & 0,27 & 3,67 & 0,31 & 0,56 & 0,51 & 53,37 & - \\
\hline $7 E$ & 0,66 & 1,63 & 1,95 & 2,47 & 5,77 & 4,33 & 0,14 & 0,22 & 3,49 & 3,19 & 0,42 & 0,50 & 16,85 & - \\
\hline $8 E$ & 0,81 & - & 2,01 & - & 7,11 & - & 0,16 & - & 11,3 & - & 0,46 & - & 14,61 & - \\
\hline $9 E$ & 0,79 & 1,40 & 1,76 & 2,31 & 7,62 & 7,77 & 0,13 & 0,19 & 8,29 & 7,59 & 0,49 & 0,55 & 11,80 & - \\
\hline
\end{tabular}

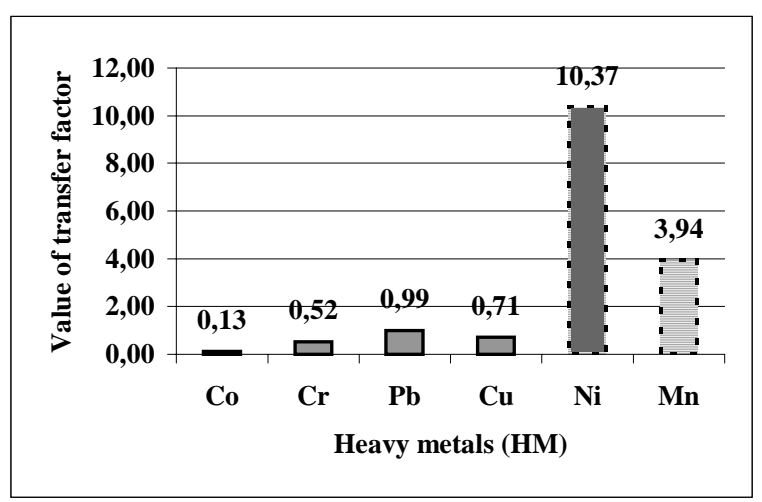

Fig 6. Transfer factor of HM transport from the soil to a birch-tree

trunk. Increase in the concentrations of $\mathrm{Mn}$ and $\mathrm{Zn}$ is especially distinct on windward side, and the decrease is determined on downwind side (Table). Variations of HM concentrations in the soil under the foliage of a birch had no particular trends.

Investigating the concentrations of $\mathrm{HM}$ at a different height of a pine trunk, it is determined that the concentrations of HM increase towards the leaves and top. Investigating the distribution of HM concentrations at a different height of a birch trunk, it is observed that larger

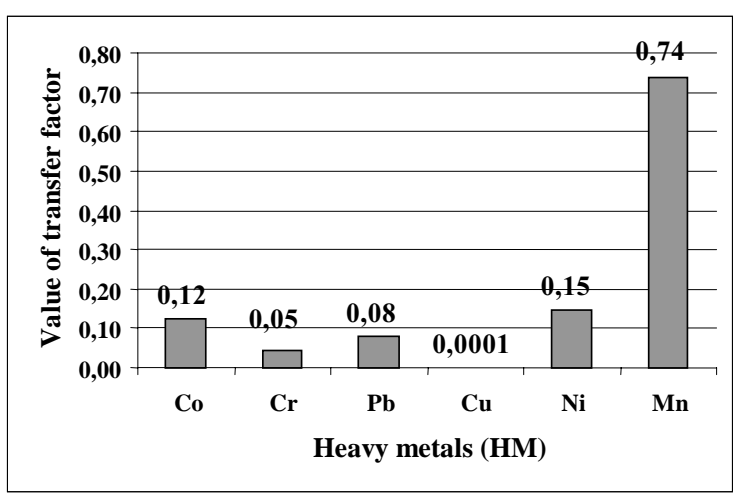

Fig 7. Transfer factor of HM transport from the soil to a pine-tree

accumulations of $\mathrm{Cr}$ and $\mathrm{Co}$ are in the middle part of the trunk.

Transfer factors for a birch-tree were calculated and are given in Fig 6 and those for a pine-tree - in Fig 7.

Concentrations of $\mathrm{Ni}$ and $\mathrm{Mn}$ increase with the soil depth. Lower concentrations of these HM in the upper soil layer can imply a zone of active uptake. $\mathrm{Mn}$ is one of those accumulated in a pine-tree with a high efficiency. 
Transfer factor was calculated to determine HM transport from the soil to pine and birch wood.

$$
F_{t}=C_{w} / C_{s}
$$

where $C_{w}$ - concentration of HM in tree wood (in the last annual ring), $\mathrm{mg} / \mathrm{kg} ; C_{s}$ - mean value of HM concentration in the soil (at a depth of $0-25 \mathrm{~cm}$ ), $\mathrm{mg} / \mathrm{kg}$.

The results from Figs 6 and 7 show that the highest values of transfer factor from the soil to the wood of both a pine and birch are typical of $\mathrm{Ni}$ and $\mathrm{Mn}$. $\mathrm{Cu}$ has the lowest concentration transferred from the soil to pinewood, whereas less Co is transported to birchwood.

\section{Conclusions}

1. $\mathrm{Pb}$ concentration under the foliage of a pine in $0-5 \mathrm{~cm}$ soil layer is approximately 2,5 times larger than the concentration of $\mathrm{Pb}$ at a depth of $20-25 \mathrm{~cm}$. A conspicuous increase in the concentration of $\mathrm{Zn}$ at the depth of the layer is perceived.

2.It is observed that the concentrations of HM have a tendency to increase in the soil around a pine on windward side towards the trunk, while that for a birch has no particular trends.

3. Concentrations of HM along the trunk of a pine were found to increase towards the leaves and top, while more $\mathrm{Co}$ and $\mathrm{Cr}$ are likely to accumulate in the middle of a birch trunk.

4. It is perceived that maximum coefficients of HM transfer from soil to wood are typical of $\mathrm{Ni}$ and $\mathrm{Mn}$. A minimum quantity of $\mathrm{Cu}$ is carried in pinewood and that of Co - in birchwood.

5. After experimental investigation on removal of $\mathrm{HM}$ from aqueous solutions the possibility of AC CKT and UPA to sorb HM from aqueous solutions was estimated.

6. The results of the investigation show that $\mathrm{AC}$ UPA is indifferent to HM. AC CKT from an aqueous solution cannot sorb HM (Co, Mn and $\mathrm{Zn})$. AC CKT includes these HM, and they can dissolve in water. The value of HM concentration in a solution depends on the mass of sorbent. When the mass of sorbent is growing, the concentration of HM in a solution is growing too.

7. According to the investigation results, HM cannot be removed from aqueous solutions with the help of AC CKT or UPA, but they can be accumulated in trees from the soil.

\section{References}

1. Markov, V. M. and others. Rational use and water treatment at machine-building enterprises. Moscow: Mashinostrojenije, 1988. 272 p (in Russian).

2. Grushko, Y. N. Harmful inorganic compounds in industrial sewage. Reference book. Leningrad: Chemistry, 1979. $160 \mathrm{p}$ (in Russian).

3. Ministry of Environment of Lithuania. Norms of sewage contamination (Lietuvos Respublikos aplinkos ministerija. Nutekamojo vandens užterštumo normos). LAND 10-96. Vilnius, 1996. 10 p (in Lithuanian).
4. Atmospheric Heavy Metals Deposition in Northern Europe 1995. Nordic Council of Ministers, Nordic Publishing House Nord, 1996. 40 p.

5. Ekvall, L; Greger, M. Effects of environmental biomasproducing factors on $\mathrm{Cu}$ uptake in two Swedish ecotypes of Pinus sylvestris. Environmental Pollution, 121 (2003), 2002, p 401-411.

6. Loppi, S; Pirintsas, S. A. Epiphytic lichens as sentinels for heavy metal pollution in forest ecosystems (central Italy). Environmental Pollution, 121(2003), 2002, p $327-$ 332.

7. Walkerhorst, A; Hagemeyer, J; Breckle, S. W. Passive Monitoring of Airborne Pollutants. Plants as Biomonitors, Indicators for Heavy Metals in the Terrestrial Environment, 1993, p 522-540.

8. Smirnov, A. D. Purification of water by sorption. Leningrad: Chemistry. 1982. 15 p (in Russian).

\section{SUNKIŲJŲ METALŲ SORBAVIMAS IŠ UŽTERŠTO VANDENS IR JŲ PERNAŠA SISTEMOJE „DIRVOŽEMIS-MEDIS“}

\section{Butkus, D. Paliulis, E. Baltrẻnaitė}

$\mathrm{S}$ a $\mathrm{n} \mathrm{t} \mathrm{r}$ a u k a

Iš technogeninių taršos šaltinių i orą, vandeni, dirvožemi ir i gamtines ekosistemas patenka dideli îvairių teršalų kiekiai. Vienos iš pavojingiausiujų ir ilgalaiki neigiamą poveiki miškų ekosistemoms turinčių medžiagu yra sunkieji metalai (SM). Jų neigiamas poveikis žmonėms, šiltakraujams gyvūnams, vandens telkiniu florai ir faunai, kanalizacijos mikroflorai kompleksinis. Paprastai sunkiuju metalu koncentracija nuotekose viršija didžiausiają leistinają koncentraciją (DLK). Nustatyta, kad SM patenka i miškus šlapiosios ir sausosios formos - iš lokaliujuc ar tolimesniujų atmosferos šaltinių; pernešami iš jūrų kartu su biogeninèmis medžiagomis ir jūros druska, išplaunami iš dirvožemyje susikaupusių supuvusių ar pūvančių augalų bei kaupiasi kartu su mineralinėmis dalelèmis, kurias atneša vejjas arba atplukdo vanduo. Darbe pasirinkta nagrinèti kelis dažniausiai pasitaikančius $\mathrm{SM}$, tokius, kaip $\mathrm{Ni}, \mathrm{Mn}, \mathrm{Zn}, \mathrm{Pb}, \mathrm{Cu}$ ir Co. Taršą SM galima būtų sumažinti, jei SM akumuliuotų augalai arba sorbuotu poringosios medžiagos. Gamtiniai arba sintetiniai sorbentai naudojami SM šalinti iš nuotekų dèl jų gana didelio sorbcinio talpumo, selektyvumo, katijonų mainų savybių, pigumo ir prieinamumo. Tyrimams buvo pasirinkti šie sorbentai: aktyvioji anglis CKT ir aktyvioji anglis UPA. Tyrimu rezultatai parodè, kad aktyvioji anglis UPA negali sorbuoti SM, o naudojant aktyviają angli CKT tirtu SM koncentracija vandeniniame tirpale dideja. Priežastis tai, kad aktyviojoje anglyje yra SM, kurie gali pereiti i tirpalą. Buvo apskaičiuotas ir SM pernašos iš dirvožemio í pušies ir beržo medieną koeficientas, tiriama SM koncentracija pušies, beržo medienoje ir dirvožemyje apie juos bei užterštame vandenyje. Medienos bandiniai buvo deginami, dirvožemio - džiovinami, o vandens mèginiai - analizuoti specialiai neparuošti. Cheminès analizès metu medienos ir dirvožemio bandiniai buvo veikiami azoto rūgštimi, o jų ištrauka ir užterštas vanduo buvo analizuojami Buck Scientific firmos atominiu absorbciniu spektrofotometru 210VGP. Nustatyta, kad efektyviausiai iš dirvožemio i pušies ir beržo medieną yra pernešami Ni ir Mn. Mažiausiai i pušies medieną pernešama $\mathrm{Cu}$, o i̇ beržo medieną - Co. 
Raktažodžiai: vandens tarša, dirvožemio tarša, mediena, sunkieji metalai, beržas, pušis, aktyvioji anglis, sorbcija, migracija, pernašos koeficientas.

\section{СОРБЦИЯ ТЯЖЕЛЫХ МЕТАЛЛОВ ИЗ ЗАГРЯЗНЕННОЙ ВОДЫ И ИХ ПЕРЕНОС В СИСТЕМЕ „ПОЧВА-ДЕРЕВО“}

\section{Д. Буткус, Д. Палюлис, Э. Балтренайте}

P е 3 ю $\mathrm{M} \mathrm{e}$

Из техногенных источников загрязнения в воздух, воду и природные экосистемы попадает большое количество разных загрязнителей. Одними из самых опасных являются тяжелые металлы. Они оказывают комплексное отрицательное воздействие на людей, теплокровных животных, фауну и флору воды, микрофлору канализации. Часто концентрация тяжелых металлов в сточной воде превышает предельно допустимые концентрации. Установлено, что тяжелые металлы попадают в леса в мокрой и сухой форме из локальных и дальних источников атмосферы, переносятся из моря вместе с биогенными материалами и морской солью, вымываются из накопившихся гнилых или гниющих в почве растений, а также с минеральными частицами, переносимыми ветром или водой. В работе иследовалось несколько наиболее часто встречающихся тяжелых металлов, таких, как $\mathrm{Ni}, \mathrm{Mn}, \mathrm{Zn}, \mathrm{Pb}, \mathrm{Cu}$ и Сo. Загрязнение тяжелыми металлами можно уменьшить, если их аккумулируют растения и сорбируют пористые вещества. Природные или синтетические сорбенты используются для удаления тяжелых металлов из сточных вод благодаря их высокой сорбционной емкости, селективности катионообменных свойств, низкой цены и доступности. Для исследований были выбраны активированный уголь СКТ и УПА. Результаты исследований показали, что ни активированный уголь УПА, ни СКТ не могут сорбировать тяжелые металлы. При применении активированного угля СКТ можно наблюдать увеличение концентрации исследуемых металлов в водном растворе, так как в состав угля входят растворимые в воде тяжелые металлы. Был установлен коэффициент переноса тяжелых металлов из почвы в сосну и березу и исследована концентрация тяжелых металлов в древесине сосны, березы и почве вокруг них, а также в загрязненной воде. Древесину сжигали, почву высушивали, а воду анализировали без специальной подготовки. Древесину и почву во время химического анализа обрабатывали азотной кислотой, а экстракт и загрязненную воду анализировали с помощью Buck Scientific атомным абсорбционным спектрофотометром 210 VGP. Было установлено, что более эффективно из почвы в древесину сосны и березы переносятся $\mathrm{Ni}$ и $\mathrm{Mn}$, менее эффективно в древесину сосны переносится $\mathrm{Cu}$, а в древесину березы $\mathrm{Co}$.

Ключевые слова: загрязнение воды, древесина, тяжелые металлы, береза, сосна, активированный уголь, сорбция, миграция, коэффициент переноса. 